\title{
Principal's Leadership Practices during the COVID 19 Pandemic: An Exploratory Study
}

\author{
Dr. John Erwin Prado Pedroso ${ }^{1} \square$ Dr. Nordy D. Siason, Jr. ${ }^{2} \square$ and Dr. Amabel Tangco- Siason ${ }^{3} \square$ \\ ${ }^{1}$ Faculty, College of Education, Professional Education Department, West Visayas State University, La Paz, Iloilo City, Philippines \\ ${ }^{2}$ Part-Time Faculty, College of Education, West Visayas State University, La Paz, Iloilo City, Philippines \\ ${ }^{3}$ Faculty, College of Education, Department of Psychology and Guidance, West Visayas State University La Paz, Iloilo City, \\ Philippines
}

$\square$ Corresponding Authors: Dr. John Erwin Prado Pedroso, E-mail: johnerwin.pedroso@wvsu.edu.ph; Dr. Nordy D. Siasion, Jr., E-mail: nordy.siason@wvsu.edu.ph; and Dr. Amabel Tangco-Siason, E-mail: atsiason@wvsu.edu.ph

\section{ARTICLE INFO}

Received: 06 October 2021

Accepted: 08 November 2021

Published: 23 November 2021

DOI: $10.32996 /$ ijahs.2021.1.1.12

\section{KEYWORDS}

Principals' Leadership Practices, COVID-19 Pandemic.

\section{ABSTRACT}

This qualitative research study looked into principals' leadership practices during the COVID-19 pandemic. It enlisted the participation of five school principals using convenient sampling based on inclusion criteria. To collect data, a semi-structured written interview based on Hersey and Blanchard's Situational leadership theory was used. To display the narratives, the data were transcribed, examined, compared, and carefully categorized into several themes. The findings reveal that school principals employed: 1. Strengths-based Practices; 2. Values-based Practices; and 3. Needs-based Practices. The findings of this study highlighted the need of applying situational leadership practices to strengthen principals' instructional and administrative duties, particularly during times of global crises.

\section{Introduction}

The role of school principals in ensuring high-quality education has been extensively researched (Romero \& Krichesky, 2018). The study of principals' leadership styles has grown in popularity as a means of improving learning circumstances by focusing on the academic aspects of school climate (Romero \& Krichesky, 2018). Recent researches have focused on how principals can improve school performance (Khanal, Perry, \& Park, 2020), the impact of culture on their decision-making (Truong, Hallinger, \& Sanga, 2017), and their significant role in providing teacher support (Elfers \& Stritikus, 2014). The breakout of the COVID-19 pandemic has become a big concern, putting a lot of strain on school principals to keep school operations running. In order to create collaboration among a broad collection of stakeholders, such as educational authorities, teachers, students, parents, and local communities, it is critical to understand their leadership styles. In a way, they are the glue that holds everything together (Whang, 2021).

Previous research on principals' leadership styles has focused on successful interactions with non-teacher members of the school community (Romero \& Krichesky, 2018), leadership techniques for producing good students (Fitriati, Romdana, \& Rosyidi, 2014), and understanding and diagnosing the school's needs (Day, Gu, \& Sammons, 2016). However, there is a scarcity of research on how responsive principals' leadership approaches were to the issues posed by the COVID-19 pandemic. The majority of the researches on this topic had been limited to quantitative analysis. Hence, a qualitative study will provide a personal context in which to comprehend the realities (Pedroso, 2021) of principals' time and context-sensitive solutions (Day, Gu, \& Sammons, 2016) in the face of the global crisis. In addition, important information on principals' leadership practices during the COVID 19 pandemic will provide a contrast to conventional educational leadership and management studies (Truong, Hallinger, \& Sanga, 2017).

The goal of this qualitative research study is to describe how principals managed the COVID-19 outbreak to ensure that school operations and learning continue. While they exhibit transformational leadership characteristics (Atasoy, 2020), their leadership styles vary across degrees of challenging circumstances (Berkovich, 2018) and have a significant impact on organizational learning (Kızıloğlu, 2021). During the pandemic, it is thought that principals took personal and context-based actions and did not seek

Copyright: (c) 2021 the Author(s). This article is an open access article distributed under the terms and conditions of the Creative Commons Attribution (CC-BY) 4.0 license (https://creativecommons.org/licenses/by/4.0/). Published by Al-Kindi Centre for Research and Development, London, United Kingdom. 
anything in return for their contributions (Shen \& Li, 2021) in the academic community. The findings of this study will highlight the importance of implementing service-oriented leadership practices to improve the instructional and administrative functions of principals. Patterns in principals' leadership practices will be used to develop more specific research questions to further investigate. Policymakers, academics, and prospective principals will benefit from this study on learning more about principals' leadership styles, especially in times of a global crisis.

\section{Literature Review}

The COVID-19 outbreak is characterized not only as a danger to social and economic cohesion but also as a threat to education and the training systems' stability and sustainability (Lifelong Learning Platform 2020; Spyropoulou \& Koutroukis, 2021), which have been disrupted as never before (United Nations, 2020; Spyropoulou \& Koutroukis, 2021). Despite the feelings of hope that the beginning of vaccinations raised, the number of new cases and the number of deaths globally, are leaving no space for complacency (Spyropoulou \& Koutroukis, 2021). With these pressing concerns amid the global crises, education goes on with school principals being at the forefront. Indeed, Pont et al. (2008) are correct in saying that school leadership does not operate in static educational environments. The expectations for schools and school leaders have changed dramatically as countries seek to adapt their education systems to the needs of modern society. School principals and teachers must be prepared to use their responsibility effectively while schools are held accountable (Gomendio, 2017) especially since the COVID-19 pandemic continues its uncontrolled trajectory all over the world (Spyropoulou \& Koutroukis, 2021). Moreover, the sudden and urgent entry and adaptation to new technologies for virtual learning, and the shifts between in-person and online teaching which unfolded, caused confusion and a great mental burden to teachers and school leaders (Anderson et al., 2020; Argyropoulou et al., 2021; Brackett and Cipriano, 2020; Educational Institute of Scotland, 2020; Spyropoulou \& Koutroukis, 2021). Limited contact with colleagues, inadequate access to resources, and poor communication from senior managers and local authority leaders, were extra pressing issues for principals while they were working from home (Educational Institute of Scotland, 2020).

With the above-mentioned premises, studies relating to school principals' leadership practices during the outbreak of the pandemic were also conducted and revealed different findings. In a study conducted in the United State, Reyes-Guerra et al. (2021) revealed that principals drew upon their individual reservoirs of shared leadership qualities, which include being a personalized and pragmatic communicator; leading with flexibility, creativity, and care; bending rules, and shifting priorities; and showing resilience under pressure. They tapped into their schools' strengths, including school context and in-house expertise. Thus, pushing principals to prioritize care, safety, and wellbeing of students, teachers, and communities above accountability measures and systemic institutional constraints. However, half of the 32 school administrators, according to Aytaç (2020), did not have an emergency response plan for the pandemic process and instead followed MoNE's (Ministry of Education in Turkey) recommendations. He also pointed out that technology leadership and crisis management abilities, according to school administrators, are crucial criteria during the pandemic process. On contrary, Kaul et al. (2020) revealed that Principals formulated their responses to the pandemic in terms of a hierarchy of needs. They understood that their students and staff had to feel physically and psychologically safe before they would be successful in the classroom. Moreover, the study of Adams et al. (2021) provided contextualized school management practices, wherein during the crisis, school leaders identified instructional and distributed leadership as critical to addressing the challenges and uncertainty that their school communities faced. According to Pollock (2020), principals are expected to be exceptional managers and excellent leaders in a time where the pace of change has increased exponentially. In her study conducted in Canada, principals in Ontario are pivoting their work. They are engaging in a two-pronged approach to lead public schools during the pandemic crisis. They are extending their roles around safe schooling and setting the context for future schooling while simultaneously extending their role of instructional leader to digital instructional leader. Principals are wrestling to create conditions for students to learn and teachers to teach, while at the same time seeking out new ways to support online learning and the operations of public schooling through what they call "extensive digital instructional leadership".

\section{Methodology}

This qualitative research study explored principals' leadership practices during the COVID-19 pandemic. It was anchored on a constructivist epistemology which sought to explore what is assumed to be a socially constructed dynamic reality through a detailed description of the phenomenon under investigation (Cerbo, 2012; Pedroso, 2020). The Situational Leadership Theory (1969) of Hersey and Blanchard was employed to highlight the interpretive perspective of this study. This theory suggests that there is no one-size-fits-all leadership style. Instead, it is determined by the style of leadership and techniques that are most appropriate for the situation. According to this perspective, the most effective leaders are those who can adjust their leadership style to the situation and consider cues such as the work at hand, the character of the group, and other elements that may help them complete the task (Kendra, 2020). Similarly, a narrative inquiry was applied in this study, which, according to Ford (2020), is an evaluation of individual human experiences-stories. Polkinghorne's paradigmatic analysis was employed in particular to look for common themes or conceptual manifestations among the stories acquired as data (Ford, 2020). 
After meeting a set of inclusion criteria, five (5) public school principals were chosen following the purposive or selective sampling technique (Jones, Brown, Holloway, 2013; Domingo, 2018, Pedroso, 2021). To provide the highest level of confidentiality and protection for the informants, the researchers assigned pseudonyms. As part of the ethical considerations that this study highlights, approved letters of information, waiver, and consent forms were also completed.

In this study, data were gathered using a researcher-made Principal's Leadership Practices Interview Form. The first section consisted of semi-structured questions provided in a table for the convenience of the informant. The informants also attached photographs in the second section to support their textual answers. This interview form was created using Google Forms and distributed to the informants using social media channels such as Facebook messenger and email. To organize, familiarize, categorize and code the data gathered, the researchers used a comparative analysis of informants' written interview transcripts (Kendra, 2020). Finally, the data was organized into themes based on situational leadership approaches including delegation, participation, selling, and telling (Kenton, 2020), which were then used to build stories (Wolcott, 1994; Domingo, 2014; Pedroso, 2021).

\section{Results}

Three themes emerged from this study's findings of school principals' leadership strategies during the COVID-19 pandemic. Their practices were based on their 1.) strengths, 2.) values, and 3.) needs. Strengths-based practices tell about strategies that recognize and capitalize on available resources, such as people, systems, and tools to maximize organizational productivity and address pressing needs during the COVID-19 pandemic. Values-based practices tell about strategies that set direction and sustain the motivation of people to lead forward in the fulfillment of the organization's goals. Needs-based practices tell about strategies that involve understanding and addressing the needs and wellbeing of people to access services, information, and resources.

\subsection{Strengths-Based Practices}

The COVID-19 pandemic is unlikely to be the final crisis we will encounter in our lifetimes, and it's not the first time school leaders have been called upon to lead in uncertain times. School leaders have faced a variety of challenges, ranging from rebuilding after natural catastrophes to assisting communities in the aftermath of economic, social, and emotional turmoil. School leaders have provided clarity and direction, created resilience, and inspired hope while remaining focused on the greatest possible outcomes for their children and school communities during difficult times (Australian Institute for Teaching and School Leadership Limited, 2020). Lyn highlighted her leadership practice by empowering members of the community and emphasizing the value of teamwork. She tells:

"Empower the teachers, student leaders, and stakeholders by giving and guiding them in their assigned tasks. Everyone has to build trust and confidence for each other and of course, appreciate and acknowledge everyone's effort for the accomplishment and success of their assigned tasks."

Mina is like Lyn who puts a lot of value on her people's strengths and capabilities. In addition, her leadership practice is anchored on celebrating the uniqueness of each person she works with. She specifies:

"Lead by embracing the uniqueness and beauty of every person by acknowledging and trusting their strengths and capacities..., let them feel appreciated"

Mina and Lyn's leadership styles may be comparable to those of other school administrators. However, their proactive and inclusive strategy, along with a transparent approach (Kerrissey and Edmonson 2020), highlights people empowerment. Their approach to the pandemic's difficult conditions may be straightforward and similar to Drago-Severson, Maslin-Ostrowski, and BlumDeStefano's (2017) highlighted practices that include collaborative problem solving, continuous learning and adaptation, utilizing different viewpoints, and shared leadership duties. Furthermore, Mina employs personal approaches that show genuine concern to her teachers. She continues:

"I am reminding the teachers to take good care of themselves. I always let them feel appreciated and acknowledged. I recognize their hard work and achievements."

Mina's idea of encouraging teachers to take care of themselves is a compassionate act (McLeod and Dulsky, 2021). After all, healthy persons are the cornerstone of the school community's talents. School administrators make every member of the school feel appreciated by recognizing individual contributions and achievements (McCallum et al. 2017). Mina further tells:

"They should know their rights, provide equal opportunities for all, and let their voices be heard." 
In the midst of the pandemic, where physical attendance in school is prohibited, Mina may have been unable to share examples of how her teachers expressed themselves. However, answers from another school principal's method of making her team members feel valued might be obtained. Nata shares:

"We get into discussions, planning, execution or implementation, monitoring, and evaluating strategies. These help them feel their worth and value as a team member."

Day, Gu, and Sammons (2016) underlined that great school leaders blend methods in multiple stages of their school's development, which is how Nata involves teachers in school operations. They are aware of and respond to the various contextual pressures they are confronted with. On the other hand, Suzi discusses the technological underpinnings of Nata's leadership methods in order to better comprehend her actions. She also depicts the involvement of various stakeholders in the context of learners' modular distance learning delivery. Suzi tells:

"We created a group chat that involved teachers, parents, guardians, learners, and stakeholders for fast and easy flow of communication and collaboration. We forged a stronger partnership with the barangay, municipal, provincial, and even private organizations to rally their support related to the modular distance learning delivery modality for our learners."

Without a doubt, Nata's practical leadership strategy is similar to Smith and Riley's (2012) clear, straightforward, and frequent communication, which is critical for conveying current information and maintaining open lines of communication. It also enhances the school's ability to effectively respond to the numerous and complicated difficulties it faces (Leithwood, 2012). In fact, media training may be beneficial to school administrators, who are themselves a vital communication conduit (Smith \& Riley, 2012). Let us clarify how school principals emphasize the importance of managing stress in order to properly carry out their professional responsibilities. Mina goes on by saying:

"Managing stress helps keep the moods and perspectives positive. This maintains good relationships in the workplace. As a leader, learning to manage one's self first is very important. Upon seeing things, a leader should act, rather than react."

Let us reflect on Mina's statement that "leaders should act". How does Nata use this to stress her leadership skills over the benefits of her subordinates? Will her function as a school principal have an impact on her subordinates' ability to preserve their inner strength during a difficult time?

"I set to myself some important things to let my people feel I am even stronger and a good influence to them that we will win over and above than the COVID threats."

Mina and Nata's thoughts revolve around preserving personal wellbeing as school principals who are expected to be excellent role models for their subordinates. Griffiths, Stevens, and Treleaven (2020, in Whitla 2003) demonstrate continuous wellness and support for others during a crisis, demonstrating the importance of managing wellbeing in times of uncertainty in schools. Furthermore, according to Fuller \& Wicking (2017), the major determinants of health and resilience are feelings of being connected, protected, and respected, or 'CPR' (Fuller \& Wicking 2017). Will it be possible to succeed as a school principal if the workforce in school is stifled? Lyn concludes:

"Lastly, protect your subordinates and look after their welfare. Listen to their concerns and deal with them with utmost tolerance and discipline. Your workforce is your strength. No matter how good the ideas and plans are, if the human resource is crippled, all our efforts won't be possible."

As school principals were banking on the well-being of the members of the school community and their strengths-based practices, the organization's performance, and productivity are at their peak,

\subsection{Values-Based Practices}

These are strategies that set direction and sustain the motivation of people to lead forward in the fulfillment of the organization's goals.

During the pandemic, Fernandez and Shaw (2020) recommended that academic leaders focus on best practices, try to see opportunities in the crisis, communicate clearly, connect with others, and distribute leadership within the organization (McLeod \& Dulsky, 2021). It is important to maintain trust during a crisis (McLeod \& Dulsky, 2021), just like Lyn who emphasized the value of transparency. Lyn shares: 
"Transparency is everything. As a leader, I have to be transparent to stakeholders and develop a sense of ownership and concern on the implementation of the school's PAPs (Programs and Projects) as reflected in BE LC+ (Basic Education Learning Continuity Plan). Thru this, they will realize that their efforts and trust will not be wasted."

Leading from a strong organizational vision and institutional values, as noted in the research literature on crisis leadership, facilitates administrators' sense-making in uncertain situations, guides critical decisions, enables coherent communication, and helps school leaders engage others in shared meaning-making (Boin et al., 2013). In line with this, Mina shares her sentiments:

"We were blinded by the situation brought about by pandemic. There is a need for a leader to have an open mind and heart and attentive ears in order to listen and give clear ideas and provide solutions to issues that come along."

The fact that Lyn emphasizes transparency and trust while Mina emphasizes openness, the principles that they both share are based on McLeod \& Dulsky's (2021) ideas regarding an old African saying " If you want to go fast, go alone. If you want to go far, go slow and go together." These administrators and their teams took the time to develop a coherent, long-term plan for how they would like to handle the job for distance learning. Furthermore, Mina reiterates the value of transparency towards having a collective decision:

"In this world under the new normal, transparent communication is a need because this encourages others to communicate openly and increases the sharing of ideas and thoughts to be able to come up with one solution or objective."

How do school principals see themselves towards their subordinates? Will their role serve as a strong platform to motivate the teachers they work with? Mina speaks:

"The only thing that keeps our teachers' enthusiasm towards work is motivation. As a leader, our primary role is to serve as a source of positivity for everyone. While leaders spread positivity, teachers become motivated to work and think well, and do great things beyond expectation."

A school leader could be a source of optimism for Mina. Will her major role support Nata's vision on how she wants to present herself to her team? Nata exemplifies:

"As a school leader, I always believe that I need to be a good influence to my team if I set myself as an example especially in times of pandemic."

Mina and Nata's perspectives on how school leaders should act as role models to their subordinates are likely to be similar. Likewise, the context of their sharing is geared toward instilling positive values in the teachers with whom they collaborate. Despite the fact that the pandemic is fast altering schooling and leadership (Bagwell, 2020), school leaders' ability to work with and through people to achieve essential results grows (Smith \& Riley, 2012). What other values transpired from the bulk of work of teachers and school principals? Lyn shares:

"One more thing, and maybe one of the most important, is to be firm. Be consistent and decisive in giving instructions among subordinates by making sure that it is bound on the Provisions of the Department of Education's Vision, Mission, and Core values. This will maintain the integrity of everyone by being consistent and having uniformity of expected outputs and outcomes from them."

Firmness, consistency, decisiveness, and integrity, as noted by Lyn in the previous share, are linked to the findings of Harris et al. (2015) on the establishment of a feeling among instructors that they are supported and respected in their efforts. In the same way, school leaders' efforts to improve teachers' willingness to try new things and learn must include facilitating trust and a sense of internal or collective accountability in which teachers hold one another to shared expectations for meeting students' needs (Bryk and Schneider, 2003; Elmore, 2007; Wahlstrom and Louis, 2008; Sahlberg, 2010; Weiner et al., 2021). Therefore, it is obvious that those well appreciated and motivated teachers are assets of the school as exemplified in the line of Nata. She says:

"...motivating and appreciating them give them a good feeling to thrive better for the school"

The COVID-19 is still sweeping the globe (Schnirring, 2020) while some schools have reopened, others have closed or shifted nearly all of their pupils to remote instruction (Sawchuk \& Gewertz, 2020). In a study conducted in Greece, it was found out that school principals faced a variety of difficulties, both on a personal level and in the context of their professional role. They also encountered difficulties above their role, which had to do with the general impact of the extended crisis on the emotional state and perceptions of the members of the school community (Spyropoulou \& Koutroukis, 2021). In this context, how does a school principal show values related to health? Gerry shares by starting: 
"Follow the leader. As a school head, follow the guidelines set by the IATF (Inter-Agency Task Force for the Management of Emerging Infectious Diseases Resolutions) in entering buildings or establishments. Wear mask and face shield properly. Without your knowledge, your subordinates are watching and will follow the same procedure."

Gerry is a school administrator who, like Nata, Lyn, and Mina, sets a good example for his followers. He emphasizes the need of adhering to safety procedures. Gerry may have realized that his personal obligation is to maintain his safety and health, while his professional role is to demonstrate the value of "followership" to the teachers who look to him for guidance. He continues:

"If face-to-face classes will be conducted, proper health protocols should be maintained. In your station, there should be a presence of different health and sanitation facilities. These facilities may include hand washing in entrance and exit, presence of thermal scanner and hand sanitizer."

In order for schools to respond effectively to critical situations, the principals' role is crucial in providing guidance, promoting a positive school climate, and empowering teachers (Day and Sammons, 2014). To set as an example, Gerry's volunteerism is evident in submitting himself for vaccination that others may emulate despite a lot of apprehensions.

"Be a role model by having yourself vaccinated to encourage your subordinates to do the same. Once you experience flulike symptoms, voluntarily, undergo self-quarantine. This will also encourage your others to do the same thing."

School principals like Gerry are selfless instructional leaders. However, being humans, they confront obstacles as well. From the start of the pandemic, principals faced the same challenges as everyone else: finding balance in new ways of living and working, as well as managing their own anxieties and concerns (Spyropoulou \& Koutroukis, 2021). Anxiety, fear, worry, shock, and sadness were the most-mentioned feelings of teachers and school leaders in the United States at the end of March 2020 (Brackett and Cipriano 2020). What could then be the best formula for success amidst the COVID-19 pandemic? Nata concludes:

"I believe self-care is important. It is vital to achieving greater success from a very threatening and stressful environment."

Despite the positivity that Nata shares in the importance of self-care, Brackett \& Cipriano (2020) argue that educators were already facing declining confidence and enormous stress, and the pandemic has only deepened that reality. However, school principals find ways of supporting and maintaining a strong sense of community. Despite the adverse circumstances, their values-based practices continue (Crawford et al. 2020; Green and Bettini 2020).

\subsection{Needs-Based Practices}

These are strategies that involve understanding and addressing the needs and wellbeing of people to access services, information, and resources during the COVID-19 pandemic.

Bagwell (2020) stated that the pandemic is "quickly changing schooling and leadership" (p. 31) and urged leaders to lead adaptively, build organizational and individual resilience, and construct distributed leadership structures for the best institutional response. Similarly, Netolicky (2020) mentioned a number of the tensions that school leaders are experiencing as a result of the pandemic. The need to lead both quickly and slowly, combining equity with excellence and accountability, and considering both human needs and organizational objectives are all examples of these conflicts. Lyn clarifies her beliefs as a school principal by saying:

"This time of pandemic has brought out either the best or the worst in us. But as leaders, worst will never be an option. Also, I do believe that we are here to work not for recognition but, we are working for the good and betterment of everyone. We love what we are doing and we love the people that we are serving."

Maybe Lyn's service as a school principal is related to the concept of "capacity building for quality instruction" which is stated in the Teaching and Learning International Survey (Rutkowski et al., 2013). As she clarifies Lyn's concept of "everyone" and "those we're serving," would Nata's thought connect to the idea of Rutkowski, et al. (2013) on principals' efforts to foster cooperation and build a feeling of responsibility among teachers? Despite Nata's emphasis on open communication, she was clear about who is responsible for the school's success. She declares:

"I always keep my line of communication open with the school teaching and non-teaching personnel, parents, learners, and stakeholders. I keep my communication lines open through social media, with family, friends, co-workers, stakeholders, and community people." 
Nata's efforts are likely to exemplify Rutkowski et al. (2013) and Gomendio's (2017) ideas about a shared sense of purpose in the school that is positively associated with distributed leadership in integrating students, parents, and guardians, and staff in school matters, as well as the need of cultivating a culture of shared responsibility. Will the idea of Nata about "line of connection" trigger inputs to other school principals on the need for technology in running school affairs? Then, how did school principals' line of communication was kept open during the COVID-19 pandemic? Suzi tells:

"We communicated regularly through our group chats, SMS (Short Messaging Services), calls, and limited face-to-face encounter."

Gerry like Suzi is emphasizing the use of technology to keep lines of communication open. As a school principal, how adept is Gerry in using social media platforms for personal and professional needs? He says:

"Constant dialogue and collaboration with all stakeholders using different communication platforms such as online meetings, using different applications such as Zoom. We can also use e-mails, SMS, or even Facebook messenger."

The need for technology is evident in the sharing of Nata and Gerry. In the educational context, the adoption level of emerging web technologies is rapidly increasing (Khan, 2021). The extensive popularity of social media in education makes it essential for teachers and students to understand and adopt social media sites to establish future educational strategies and deploy present course materials on emerging technology-powered platforms (Sarwar et al., 2019; Bai et al., 2021; Khan, et al., 2021) such as Zoom (Adnan, 2020; Khan, 2021) and Facebook (Ramsha, 2021; Khan, 2021). Indeed, social media platforms disseminate and communicate information while also creating a collaborative environment (Esam and Hashim, 2016) like in the case of Nata and Gerry. Mina did not share about social media platforms, but her perspective on how to act on urgent school concerns is commendable. She tells:

"We're happy if our concerns were addressed immediately. We're happy if our goals were achieved. It is a great achievement if a leader was able to immediately address pressing issues and matters that need the utmost decision. If the situation needs urgent action, a leader should decide and act immediately and appropriately for the good of all."

Given the increased complexity and diversity of situations that require immediate solutions, academic leaders will be making innovative decisions and will be responding to the needs (Al-Dabbagh, 2020; Dumulescu \& Muţiu, 2021) like Mina. Likewise, the humanist spirit of trust and openness, to generate an organizational culture of solidarity and cooperation" (David, 2020; Dumulescu \& Muţiu, 2021) is important for a school principal. What then should principals do in order for them to address the different needs of the school community? Nata says:

"Planning and preparing are very important in brainstorming for action-oriented strategies with your leadership team."

The information shared by Nata serves as the overall approach of school principals in dealing with school concerns. Also, Lyn elaborates that she is conducting collective consultation among her constituents and considering their safety. Similar to the findings of Siason (2021), that on top of achieving their goal of implementing a responsive Learning Continuity Plan (LCP), school heads are noted to prioritize the welfare of their teachers, staff, and learners by following IATF guidelines and health protocols. Lyn tells:

"I dealt with School's BE LCP+ (Basic Education Learning Continuity Plan+) through collective consultation with teachers and stakeholders upon which programs, activities, and projects are to be prioritized in lieu with continuity of learning activities. It helps us manage our resources, efforts, and time well while maintaining the security and safety of everyone."

On the other hand, the sharing of Suzi emphasizes her leadership practices based on the needs of her constituents and the school community as a whole. She vividly recalls how she implemented programs according to the mandates of the Department of Education. Suzi enumerates:

"I led the personnel in assessing their development needs, preparing their IPPD (Individual Plan for Professional Development), consolidating their needs (common and unique needs), preparing the SPPD (School Plan for Professional Development), planning the $L$ and $D$ (Learning and Development) interventions, gathering and compiling quality-assured resource packages, delivering the planned interventions through various modalities, as well as monitoring and evaluating conducted interventions." 
"I led in the amendment of the proposal, utilization, liquidation of financial obligations, and reporting of our financial transactions through our Transparency Board and other reporting mechanisms as part of our compliance to ARTA (Anti-Red Tape Authority)."

Suzi, also discussed how she managed school financial resources to ensure that school services were delivered efficiently. Her swift handling of financial issues was a reaction to the school's pressing requirements. She further tells:

"Maximizing limited procurement of supplies MOOE (Maintenance and Other Operating Expenses) funds in this time of pandemic was a challenge to us. However, with the approved AIP (Annual Implementation Plan) in place which was prepared by the School Planning Team last quarter of last year, this challenge was handled promptly with minor revisions to address the urgent needs of the school which were focused on the procurement of supplies, materials, and equipment in the reproduction of SLMS (Self-Learning Modules), transportation allowance of teachers in the distribution and retrieval of modules, procurement of supplies and materials related to the prevention of COVID-19 infection of school personnel and learners."

Suzi's specific actions are helpful in better understanding Lyn's idea for implementing collective consultation with her constituents. Suzi's work is mostly focused on her real context (Rowley, 2002; Dumulescu \& Muţiu, 2021) as a school principal. Maintaining strong connections with teachers, staff, students, and parents proved to be crucial in managing the pandemic (Brackett et al. 2020; Spyropoulou \& Koutroukis, 2021). Collaboration, communication, availability, and access to information, infrastructure, and services were all variables that aided principals in crisis management in the school context (Hubbard et al. 2020; Spyropoulou \& Koutroukis, 2021) during the pandemic. Suzi continues her sharing on how she collaborated with her teaching and non-teaching staff. She speaks:

"Teachers were assigned as learning facilitators in particular catchment areas of the school which considered the proximity of their residence with that of the learners for their safety and protection. I ensured that our teaching and non-teaching personnel are taken care of especially their psychological/mental, physical, social, and spiritual health."

Subjectively, Lyn, Gerry, Nata, Mina, and Suzi could be described by the ideas of Eva et al., (2019; Dumulescu \& Muţiu, 2021) on servant leadership that focuses on the motivational and aspirational aspects and recognizes followers' need for psychological support and belonging. It also suggests that if followers are treated as ends in themselves, rather than a means to an end, they will reach their potential and will perform optimally even in crisis (Waterman, 2011; Dumulescu \& Muţiu, 2021) which were specifically reflected in the ideas of Suzi. Furthermore, Mina articulated practical approaches to address different needs. She tells:

"Stress will be regulated if leaders communicate effectively with the team, prioritize tasks and delegate, visualize things and plan accordingly, encourage coffee break to improve wellness and well-being, promote workplace wellness, allow flexible work arrangements, and ensure that teachers get support in their career, and promote balance between work and family."

The ideas of Mina in the preceding sharing could be her personal counter-actions towards the effects of COVID-19 on mental health (Mahase, 2020; Spyropoulou \& Koutroukis, 2021). Because of the unique nature of the COVID-19 crisis, which involves a great deal of stress and uncertainty, the leader's personality traits and leadership style are critical in fostering trust and responsibility within the organization. From this perspective, servant leadership, which emphasizes a collaborative, sympathetic, and emotionally stable leader personality can contribute to the development of a strong community by focusing on the needs of the organization's members (Doraiswamy, 2012; Dumulescu \& Muţiu, 2021). Similarly, Nata suggests that addressing personal needs to be able to lead effectively is important. She says:

"I always practice good healthy lifestyle on choosing and eating healthy organic foods, getting enough sleep, doing daily exercise. I am doing this so that I can lead effectively our school and be of help to the community if I am well."

To lead effectively, you must be willing to help others wholeheartedly, like what Suzi is doing after attending webinars with her teachers. Webinars are online seminars that take place over the internet. They can be meetings, conferences, demonstrations, training or teaching, or events that are aimed to provide information in a one-way or interactive manner to students and teachers from the comfort of their homes and workplaces (White, 2019; Pedroso, 2021). Suzi continues:

"After every, webinar, we conducted follow-up activities such as coaching, LAC (Learning Action Cells) sessions, jobembedded learning, and peer-assisted learning to ensure the transfer of learning in the workplace and to improve the work performance in terms of efficiency, effectiveness, and timeliness." 
"I also capacitated them in preparing standard-compliant summative assessments and in monitoring, evaluating and providing assistance to learners through various communication platforms."

"I also led them in understanding and internalizing the importance of the Weekly Home Learning Plan and the Individual Learner's Monitoring Plan through LAC (Learning Action Cells) sessions, coaching, job-embedded learning activities, and peer-assisted learning with the aid of technology."

Khan et al., (2021) tell social media platforms to provide an alternative to face-to-face discussions. Thus, the role of social media for educational purposes has become more significant, as it enhances connectivity and brings collaborative opportunities (Islam et al., 2020; Khan, et al., 2021). Social Media tools enable teachers, students, and academic institutions to overcome COVID-19 induced restrictions. Furthermore, digital technologies are increasingly used in the business and educational sectors. On a societal level, increased digital technology use enables people worldwide to keep in touch (Dwivedi et al., 2020; Khan et al., 2021). Thus, Gerry was well-connected to his constituents with the help of technology to discuss important school concerns. Gerry speaks:

"...frequent online meetings with your staff and colleagues to update everybody about important topics or concerns"

According to studies, effective leaders focus on learning experiences, have emotional agility, and the ability to acknowledge fear (Koehn, 2020; Dumulescu \& Muţiu, 2021), like the school principals in this study. Literature also mentioned competencies needed to overcome the challenges associated with the COVID-19 crisis such as flexibility, accounting for emotions, attention to other opinions, and engagement (Schwantes, 2020; Dumulescu \& Muţiu, 2021). Some studies emphasized important roles and traits of leaders in times of crisis like being a sense maker, being a technology enhancer, having emotional stability, and emphasizing employee wellbeing and innovative communication in order to maintain the stability of the organization (Dirani et al., 2020; Dumulescu \& Muţiu, 2021). Among these concepts of leadership mentioned in which competencies does Suzi fit in as she attends to the needs of her constituents as she says:

"I also recommended them to attend learning and development activities based on their development needs."

Will Nata, like Gerry fit what Dirani et al. (2020) and Dumulescu and Muţiu, (2021) emphasized as "technology enhancer"? She tells:

"I do listen to updates from valid social media platforms."

School principals must learn to adjust their leadership styles to successfully manage people and to effectively address the needs of the community (Siason et al., 2021). The school principals were attentive to the needs of the school community during the COVID-19 pandemic. They have transformational and visionary roles (Settles et al., 2019; Dumulescu \& Muţiu, 2021) which kept the educational institutions afloat through their needs-based practices (Dumulescu \& Muţiu, 2021).

\section{Conclusion}

The organizational responsibility of school principals is to leverage the potentials and abilities of stakeholders in order to transform pandemic impediments into development opportunities. They are in charge of increasing the organization's efficiency and productivity. They have a moral obligation to serve as role models for their stakeholders, encouraging others to emulate positive values. Despite the health and education crises, they must promote virtues and ethical behaviors in order to sustain organizational integrity. Finally, school principals have the professional responsibility and operational accountability of molding the school environment for the safety of all stakeholders and enabling teachers to accomplish their jobs through technology-assisted capacity-building initiatives. During the pandemic, they are in charge of developing support services to assist in addressing the health crisis as well as providing access to resources and information technology.

Acknowledgments: The researchers wish to express their heartfelt gratitude to everyone who helped and made this study work feasible in some way. To God be the glory!

Funding: This research received no external funding.

Conflicts of Interest: The authors declare no conflict of interest.

\section{References}

[1] Adams, D., Cheah, K. S. L., Thien, L. M., \& Md Yusoff, N. N. (2021). Leading schools through the COVID-19 crisis in a South-East Asian country. Management in Education. https://doi.org/10.1177/08920206211037738

[2] Adnan, M. (2020). Online learning amid the Covid-19 pandemic: students' perspectives. J. Pedagogical Social. Psychol. 1, 45-51. DOI: 10.33902/jpsp.2020261309 
[3] Argyropoulou, E, Christina E. S and Markos P. (2021). School Leadership in Dire Straits: Fighting the Virus or Challenging the Consequences? International Studies in Educational Administration 49: 18-27. Available online:https://www.academia.edu/44571628/School_Leadership_in_Dire_Straits_Fighting_the_Virus_or_Challenging_the_Consequences

[4] Al-Dabbagh, Z. S. (2020). The role of decision-maker in crisis management: a qualitative study using Grounded Theory (COVID-19 pandemic crisis as a model). J. Public Affairs 20: e2186. DOI: 10.1002/pa.2186

[5] Andersen, K.G., Rambaut, A., Lipkin, W.I. et al. The proximal origin of SARS-CoV-2. Nat Med 26, 450-452 (2020). https://doi.org/10.1038/s41591-020-0820-9

[6] Atasoy, R. (2020). The Relationship between School Principals' Leadership Styles, school Culture and Organizational Change. International Journal of Progressive Education, v16 n5 p256-274, EJ1273161

[7] Australian Institute for Teaching and School Leadership Limited (2020). The role of school leadership in challenging times. https://www.aitsl.edu.au/research/spotlight/the-role-of-school-leadership-in-challenging-times ABN 17117362749

[8] Aytaç, T. (2020). European Journal of Educational Sciences, 7(4), ISSN: 1857- 6036, Doi:10.19044/ejes. v7no4a5

[9] Bagwell, J. (2020). Leading through a pandemic: adaptive leadership and purposeful action. J. School Adm. Res. Dev. 5, 30-34. DOI: 10.32674/jsard. v5iS1.2781

[10] Bai, J., Mo, K., Peng, Y., Hao, W., Qu, Y., Lei, X., et al. (2021). The relationship between the use of mobile social media and subjective wellbeing: the mediating effect of boredom proneness. Front. Psychol. 11:568492. DOI: 10.3389/fpsyg.2020.568492

[11] Berkovich, I. (2018). When the going gets tough: Schools in challenging circumstances and the effectiveness of principals' leadership styles. Journal of Community and Applied Social Psychology, 28(5), 384-364 https://doi.org/10.1002/casp.2372

[12] Boin, Arjen \& Overdijk, Werner \& Kuipers, Sanneke. (2013). Leadership in Times of Crisis: A Framework for Assessment. International Review of Public Administration. 18. 79-91. 10.1080/12294659.2013.10805241.

[13] Brackett, M., Cannizzaro, M., and Levy, S. (2020). The pandemic's toll on school leaders is palpable. Here's what's needed for a successful school year. EdSurge. Available online: https://www.edsurge.com/news/2020-07-16-the-pandemic-s-toll-onschool-leaders-is-palpablehere-s-what-s-needed-for-a-successful-school-year

[14] Bryk, A. S., and Schneider, B. (2003). Trust in schools: a core resource for school reform. Educ. Leadersh. 60, 40-45.

[15] Cerbo, C. A. (2012). A Glimpse of Pisay History through Oral history as an Instructional Methodology in Teaching Social Science I. Unpublished Dissertation, West Visayas State University. La Paz, Iloilo City, Philippines.

[16] Crawford, Alison, Laura A. Currie, Beth Hannah, Jacqui Ward, and Imogen Wooton. 2020. Compassionate Transitions: Reconnecting School Communities Post-Covid-19 Closures. British Psychological Society.

[17] David, D. (2020). PROGRAMUL ProUBB+, UBB - Universitate de Clasă Mondială (World-Class) Prin Încredere şi Deschidere. Retrieved from: https://danieldavid.ro/wp-content/uploads/2020/01/Daniel-David-Programul-ProUBBFinal.pdf

[18] Day, C., Gu, Q., \& Sammons, P. (2016). The Impact of Leadership on Student Outcomes: How Successful School Leaders Use Transformational and Instructional Strategies to Make a Difference. EducationalAdministrationQuarterly, 52(2),221258. https://doi.org/10.1177/0013161X15616863

[19] Dirani, K. M., Abadi, M., Alizadeh, A., Barhate, B., Garza, R. C., Gunasekara, N., et al. (2020). Leadership competencies and the essential role of human resource development in times of crisis: a response to Covid-19 pandemic. Hum. Resour. Dev. Int. 23, 380-394. DOI: 10.1080/13678868.2020.1780078

[20] Domingo, J.P. R. (2018). Direct from the Connoisseurs: Articulating Philippine Folk Dance Documentation Practices. https://www.dlsu.edu.ph/wp-content/uploads/pdf/conferences/research-congress-proceedings/2018/li-21.pdf

[21] Doraiswamy, I. R. (2012). An analysis of servant leadership in family-owned businesses. Int. J. Soc. Sci. Interdiscipl. Res. 1, $169-174$.

[22] Drago-Severson, E., Maslin-Ostrowski, P., \& Blum-Destefano, J. (2018). Looking behind the Curtain: Principals' Internal Experiences of Managing Pressing Challenges. Journal of School Leadership, 28(3), 315-343. https://doi.org/10.1177/105268461802800303

[23] Dumulescu, D. \& Muţiu, Al. (2021) Academic Leadership in the Time of COVID-19—Experiences and Perspectives. Front. Psychol. 12:648344. DOI: $10.3389 /$ fpsyg.2021.648344

[24] Dwivedi, Y. K., Hughes, D. L., Coombs, C., Constantiou, I., Duan, Y., Edwards, J. S., et al. (2020). Impact of a covid-19 pandemic on information management research and practice: transforming education, work, and life. Int. J. Inform. Manag. 55:102211. DOI: 10.1016/j.ijinfomgt.2020.102211

[25] Educational Institute of Scotland. (2020). Teaching during the Covid-19 Shutdown. Available online: https://www.eis.org.uk/Content/ images/corona/SurveyResults.pdf

[26] Elfers, A. M., \& Stritikus, T. (2014). How School and District Leaders Support Classroom Teachers' Work with English Language Learners. Educational Administration Quarterly, 50(2), 305-344. https://doi.org/10.1177/0013161X13492797

[27] Elmore, R. F. (2007). School Reform from the Inside Out: Policy, Practice, and Performance.Cambridge, MA: Harvard Education Press.

[28] Esam, N. M., and Hashim, N. (2016). The impact of social media uses on academic performance among UITM Puncak Perdana students. Res. Hub 2, 16-23. Available online at: https://researchhub.uitm.edu.my/pdf/Hidayah1.pdf

[29] Eva, N., Robin, M., Sendjaya, S., van Dierendonck, D., and Liden, R. C. (2019). Servant leadership: a systematic review and call for future research. Leadersh. Q. 30, 111- $\quad$ 132. DOI: 10.1016/j.leaqua.2018.07.004

[30] Fernandez, A.A, \& Shaw, G. P (2020). Academic Leadership in a Time of Crisis: The Coronavirus and COVID-19, Journal of Leadership Studies, 14(1), Springer 202, 39-45 https://doi.org/10.1002/jls.21684

[31] Ford, E. (2020). Tell Me Your Story: Narrative Inquiry in LIS Research. College \& Research Libraries, 81(2), 235. doi:https://doi.org/10.5860/crl.81.2.235

[32] Fitriati, R., Romdana, R., \& Rosyidi, U. (2014). The Practice of the School Principal's Leadership in Sekolah Indonesia Kuala Lumpur (SIKL): The Study of Leadership Styles and Techniques with Cognitive Mapping Approach, Procedia - Social and Behavioral Sciences, Volume 115 258268, ISSN 1877-0428. https://doi.org/10.1016/j.sbspro.2014.02.434.

[33] Fuller, A \& Wicking, A. (2017), 'Innovative practices for building resilient schools', Professional Educator, 16 (2), 8-10, https://www.austcolled.com.au/wp-content/uploads/2018/01/Prof-Ed-Vol-16-Issue-2.pdf. 
[34] Green, Jennifer G., and Elizabeth Bettini. 2020. Addressing Teacher Mental Health during the COVID-19 Pandemic. Teachers College Record. Available online: https://www.researchgate.net/publication/343360704_Addressing_Teacher_Mental_Health_during_the_COVID19_Pandemic/link/5f2ac16f299bf13404a3e1fb/download

[35] Griffiths, K, Stevens, K, \& Treleaven, J. (2020), Trauma-informed practice in schools: An explainer, Centre for Education Statistics and Evaluation, Sydney, N.S.W, https://www.cese.nsw.gov.au//images/stories/PDF/trauma-informed-practice.pdf.

[36] Gomendio, M. (2017. Empowering and Enabling Teachers to Improve Equity and Outcomes for All, International Summit on the Teaching Profession, OECD Publishing, Paris. http://dx.doi.org/10.1787/9789264273238-en

[37] Harris, A., Adams, D., Jones, M. S., and Muniandy, V. (2015). System effectiveness and improvement: the importance of theory and context. School Effect. Sch. Improv. 26, 1-3. DOI: 10.1080/09243453.2014.987980

[38] Hubbard, L., Hollie Mackey, H. \& Supovitz, J, A. (2020). District Response to the COVID-19 Pandemic. CPRE Policy Briefs. Available online: https://repository.upenn.edu/cpre_policybriefs/88

[39] Islam, A. N., Laato, S., Talukder, S., and Sutinen, E. (2020). Misinformation sharing and social media fatigue during COVID-19: an affordance and cognitive load perspective. Technol. Forecast. Soc. Change 159:120201. DOI: 10.1016/j.techfore.2020.120201

[40] Jacobs, H \& Zmuda, A. (2020) 'We did not sign up for this! 9 lessons learned from a Hong Kong principal on facing a crisis', Learning Personalized, https://www.learningpersonalized.com/we-did-not-sign-up-for-this-9-lessons-learned-from-a-hong-kong-principal-onfacing-a-crisis.

[41] Jones, L. Brown, L. \& Holloway, I. (2013). Qualitative research in sp[ort and physical activity. Thousand Oaks, California: Sage

[42] Kaul, M. VanGronigen, Bryan A.; \& Simon, N. (2020). Calm during crisis: school principal approaches to crisis management during the COVID-19 pandemic. CPRE Policy Briefs. Consortium for Policy Research in Education, Philadelphia, PA. Retrieved from https://repository.upenn.edu/cpre_policybriefs/89

[43] Kendra, C. (2020). The Situational Theory of Leadership. https://www.verywellmind.com/what-is-the-situational-theory-of-leadership2795321

[44] Kerrissey, M \& Edmondson, A. (2020). 'What good leadership looks like during this pandemic', Harvard Business Review, https://hbr.org/2020/04/what-good- leadership-looks-like-during-this-pandemic.

[45] Khan MN, Ashraf MA, Seinen D, Khan KU and Laar RA, (2021). Social Media for Knowledge Acquisition and Dissemination: The Impact of the COVID-19 Pandemic on Collaborative Learning-Driven Social Media Adoption. Front. Psychol. 12:648253. DOI: 10.3389/fpsyg.2021.648253

[46] Khanal, J., Perry, F., \& Park, S.-H. (2020). Leadership practices of principals of high-performing community high schools: Evidence from Nepal. Educational Management Administration \& Leadership, 48(6), 1026-1045. https://doi.org/10.1177/1741143219884076

[47] Kızıloğlu, M. (2021). The impact of school principal's leadership styles on organizational learning: Mediating effect of organizational culture, bmij (2021) 9 (3): 822-834, DOl: $\quad$ https://doi.org/10.15295/bmij.v9i3.1814

[48] Koehn, N. F. (2020). Real leaders are forged in crisis. Harvard Business Review (website).

[49] Leithwood, K, Harris, A \& Hopkins, D (2020). Seven strong claims about successful school leadership revisited', School Leadership and Management, 40 (1),5-22 https://doi.org/10.1080/13632434.2019.1596077.

[50] Lifelong Learning Platform. (2020). COVID-19: Mental Health and Wellbeing of All Learners Come First. Available online: HTTP: //IIlplatform.eu/III/wp-content/uploads/2020/12/LLLP-Statement-COVID-19_EMDR-update.pdf

[51] Mahase, E., (2020). Covid-19: Mental health consequences of pandemic need urgent research, the paper advises. BMJ 369: m1515. Available online: https://pubmed.ncbi.nlm.nih.gov/32299806/

[52] McCallum, F, Price, D, Graham, A \& Morrison, A. (2017). Teacher wellbeing: A review of the literature, Association of Independent Schools of NSW, Sydney, N.S.W, https://apo.org.au/node/201816.

[53] McLeod, S. \& Dulsky, S. (2021), Resilience, reorientation, and reinvention: School leadership during the early month of the COVID-19 pandemic, Frontiers in Education, https://doi.org/10.3389/feduc.2021.637075

[54] Netolicky, D. M. (2020). School leadership during a pandemic: navigating tensions. J. Prof. Capacity Commun. 5, 391-395. DOI: 10.1108/JPCC-05-2020-0017

[55] Pedroso, J.E.P. (2020). Understanding Casa Mariquit as an Ilonggo Cultural Heritage Site: Towards the Development of a Video Documentary Instructional Material, BIMP-EAGA Journal of Sustainable Tourism Development, 9(1), 40-51. DOI: https://doi.org/10.51200/bimpeagajtsd.v9i1.3247

[56] Pedroso, J.E.P. (2021). Students' Views from Webinars: A Qualitative Study. International Journal of Arts and Humanities Studies (IJAHS), 1(1), 36-44. ISSN: 2754-4311, DOI: 10.32996/Elijah

[57] Pollock, K. (2020). School Leaders' Work During the COVID-19 Pandemic: A Two-Pronged Approach, International Studies in Educational Administration, 48(3), 38-44. https://www.edu.uwo.ca/faculty-rofiles/docs/other/pollock/School-Leaders-Work-During-theCOVID-19-Pandemic-A-Two-Pronged-Approach.pdf

[58] Pont, B., Nusche, D., \& Moorman, H. (2008). Improving school leadership, volume 1: policy and practice - ISBN 978-92-64-04467-8 - (c) OECD 2008

[59] Ramsha, J. (2020). "Social media outlets see a surge in a number of Pakistani users." Dawn. Available online at: https://www.dawn.com/news/1548993

[60] Reyes-Guerra D, Maslin-Ostrowski P, Barakat MY and Stefanovic MA (2021) Confronting a Compound Crisis: The School Principal's Role During Initial Phase of the COVID-19 Pandemic. Front. Educ. 6:617875. DOI: 10.3389/feduc.2021.617875

[61] Romero, C., \& Krichesky, G. (2018). Interactive leadership in turbulent school climates. An exploratory study of high school principals from the City of Buenos Aires. Educational Management Administration \& Leadership, 46(2), 339-354. https://doi.org/10.1177/1741143217720456

[62] Rowley, J. (2002). Using case studies in research. Manag. Res. News 25, 16-27. DOI: 10.1108/01409170210782990

[63] Rutkowskiet, D., Rutkowski, L., Bélanger, J., Knoll, S., Weatherby, K., \& Prusinski, E. (2013). The TALIS 2013 ConceptuaL Framework, Organisation for Economic Co-operation and Development (OECD). https://www.oecd.org/education/school/TALIS\%20Conceptual\%20Framework_FINAL.pdf

[64] Sahlberg, P. (2010). Rethinking accountability in a knowledge society. J. Educ. Change 11, 45-61. DOI: 10.1007/s10833-008-9098-2 
[65] Sarwar, B., Zulfiqar, S., Aziz, S., and Ejaz Chandia, K. (2019). Usage of social media tools for collaborative learning: the effect on learning success with the moderating role of cyberbullying. J. Educ. Comput. Res. 57, 246-279. DOI: 10.1177/0735633117748415

[66] Sawchuk, S. \& Gewertz, C. (2020). Schools Are Retreating to Remote Learning as COVID-19 Surges. Do They Have To? https://www.edweek.org/leadership/schools-are-retreating-to-remote-learning-as-covid-19-surges-do-they-have-to/2020/11

[67] Schnirring, L. (2020). Europe Weighs COVID-19 Steps as Global Total Tops 59 Million. Minneapolis, MN: Center for Infectious Disease Research and Policy.

[68] Schwantes, M. (2020). 4 Signs to Instantly Identify a Great Leader during Crisis. Inc. https://www.inc.com/marcel-schwantes/great-leadertime-of-crisis.html

[69] Settles, I. H., Brassel, S. T., Soranno, P. A., Cheruvelil, K. S., Montgomery, G. M., and Elliott, K. C. (2019). Team climate mediates the effect of diversity on environmental science team satisfaction and data sharing. PLoS One 14: e0219196. DOI: 10.1371/journal.pone.0219196

[70] Shen, C.T. \& Li, X. (2021). Secondary School Principals' Leadership Behavioral Characteristics that Inspire Teachers' Gratitude in Taiwan. Journal of China-ASEAN Studies. 1(2), 40-47.

[71] Siason, N. Jr., (2021). Twists and turns in school-based management: Experiences of school heads in the new normal. Turkish Online Journal of Qualitative Inquiry (TOJQI). 12 (7), 13848-13882

[72] Siason, N. Jr., Sumande, D. \& Dilag, C. (2021). School heads' leadership style as related to teachers' emotional intelligence, productivity, and performance: Bases for the development of an enhanced school-based in-service training program. Turkish Online Journal of Qualitative Inquiry (TOJQI). 12 (7), 13710-13722

[73] Smith, L., \& Riley, D. (2012). School leadership in times of crisis. School Leadership \& Management, 32, 57 - 71. https://doi.org/10.1080/13632434.2011.614941

[74] Spyropoulou, E. \& Koutroukis, T. (2021). Managing Open School Units Amid COVID-19 Pandemic through the Experiences of Greek Principals. Implications for Current and Future Policies in Public Education. Administrative Sciences 11:70. https://doi.org/10.3390/admsci11030070

[75] Truong, T. D., Hallinger, P., \& Sanga, K. (2017). Confucian values and school leadership in Vietnam: Exploring the influence of culture on principal decision making. Educational Management Administration \& Leadership, 45(1), 77-100. https://doi.org/10.1177/1741143215607877

[76] United Nations (2020). Policy Brief: Education during COVID-19 and Beyond. Available online: https://unsdg.un.org/sites/default/ files/202008/sg_policy_brief_covid-19_and_education_august_2020.pdf

[77] Wahlstrom, K. L., and Louis, K. S. (2008). How teachers experience principal leadership: the roles of the professional community, trust, efficacy, and shared responsibility. Educ. Admin. Q. 44, 458-495. DOI: 10.1177/0013161X08321502

[78] Waterman, H. (2011). Principles of 'servant leadership and how they can enhance practice. Nurs. Manag. 17, 24-26. DOI: 10.7748/nm2011.02.17.9.24.c8299

[79] Weiner J, Francois C, Stone-Johnson C and Childs J (2021) Keep Safe, Keep Learning: Principals' Role in Creating Psychological Safety and Organizational Learning During the COVID-19 Pandemic. Front. Educ. 5:618483. DOI: 10.3389/feduc.2020.618483

[80] Whang, C. (2021). The role of school heads and why they matter during the COVID pandemic. OECD Education and Skills Today. https://oecdedutoday.com/role-school-principals-heads-covid/

[81] White, A. (2019). Reflections on the Use of Webinar Technology for Teaching. 2019. ffhal-01976364f

[82] Whitla, M. (2003). Crisis management and the school community, ACER Press, Camberwell.

[83] Wolcott, H.F. (1994). Transforming qualitative data: Descriptions, analysis, and interpretation. Thousand Oaks, CA: Sage.

[84] World Health Organization (2020), Mental health: a state of well-being, WHO, http://origin.who.int/features/factfiles/mental_health/en/. 